\title{
ANALYSIS OF PROFITABILITY AND POVERTY REDUCTION OF YOGHURT PROCESSING INDUSTRIES IN MAIDUGURI METROPOLITAN AREA OF BORNO STATE, NIGERIA
}

I.M. ALI, I.M. SULUMBE AND B.G. SHETTIMA

(Received 13, December 2008; Revision Accepted 26, January 2010)

\begin{abstract}
The study assessed the profitability of yoghurt processing with a view of determining its potentials for reducing poverty in Maiduguri Metropolitan Area. Data were collected from a survey of 10 yoghurt processing firms in Maiduguri and analysed using profit model and descriptive statistics. Results revealed that yoghurt proprietors in the study area were mostly males (70\%) who were in their active age group of 36-45 years. Profitability analysis revealed that yoghurt processing was profitable with mean profit value of $\mathrm{N} 9,612.47 \mathrm{k}$ per $25 \mathrm{~kg}$ of milk processed, and that it reduces the poverty level as it provides employment opportunities for 5 persons per firm as at he time of the study.
\end{abstract}

KEY WORDS: Profitability, poverty reduction, yoghurt, processing, employment

\section{INTRODUCTION}

Poverty in literature is considered from economic and cultural perspectives. The economic perspective emphasizes the disposable income required to support a minimum standard of decent living (Booth, 1989). The cultural perspective gives prominence to internal attitudes and behavioural patterns an individual may bring to a given set of circumstances.

The poverty line in theory can be defined as the monetary cost to a given persons, at a given place and time, of a reference level of welfare. People who do not attain that level of welfare are poor and those who do are not (Ajakaiye and Adeyeye, 2001). In Nigeria, the per capita income was $\$ 560$ in 2005 (World Bank, 2007). Poverty, food insecurity and malnutrition are prevalent throughout Nigeria (Innovative Experiences, 1998).

The World Bank in 1996 identified unemployment as one of the obvious causes of poverty which in turn limits the ability of a man to contribute to and benefit from development. The unemployment rate is about $17 \%$ in Nigeria (Federal Ministry of Labour and Productivity, 2004) and affects all sectors of the economy. This could be attributable to imbalance in labour supply and demand as well as population growth. The evident unemployment of labour in a land-surplus economy can, therefore, be seen as an indication of inefficiency in resource use, loss of GNP and is capable of bringing social unrest with its attendant negative consequences.

Agriculture provides employment for more than $70 \%$ percent of the rural working population (Joshua, 1999). With about 76 out of every 120 people living below the poverty line (Okuneye, 2002), it would appear one of the core objectives of its macroeconomic policy (Fakiyesi, 2001). This is aimed amongst others in the training and provision of credit in the agricultural sector.

Yoghurt processing industry is an agro-allied based industry that depends on agriculture products directly for its raw materials. Cow milk is the predominant raw material for manufactured dairy products. Dairy products obtained from milk include cheese, sour cream, yoghurt and butter (fat) milk.

Yoghurt processing is relatively simple. It is a cultured dairy product produced by lactic fermentation of milk (Boukar, 2004). This can be made from whole milk or skimmed milk from animals especially cow. Yoghurt is beneficial to man as an excellent source of protein and calcium. Increase in the consumption of the product especially in developing economies like Nigeria, can be attributed to increased awareness of its nutritional value as well as relatively improved earnings (F.G N Pension Reform Act, 2004).

In Maiduguri Metropolitan Council Area (M.M.C.A) this increased demand for yoghurt has manifested in the sprouting-up of many small-scale yoghurt processing industries where people are normally employed. The yoghurt processing industries are mostly owned by sole proprietors who seek to make profit from their investments and at the same time create job opportunities for their employees. The poverty level is still very high in the country (Okuneye, 2002) and agriculture has not been able to salvage the situation. At this juncture, therefore, it is pertinent to ask the following questions: Can these industries successfully provide

I.M. Ali, Department of Agric Economics and Extension, Universitebof Maidugumi, Bornepstates, Nigariat processing in

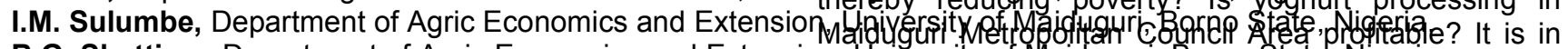

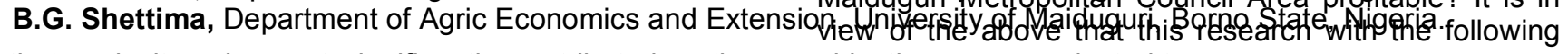
that agriculture has not significantly contributed to the reduction of poverty in the country.

It is in realization of the high level of poverty in the country that government embraced poverty reduction as

objectives was conducted to:

i. examine the socio-economic characteristics of sole proprietors of yoghurt processing industries in M.M.C.A 
ii. determine the profitability of yoghurt processing in M.M.C.A.;

iii. determine the mean employment level and contribution to poverty reduction in the study area; and

iv. identify the problems of yoghurt processing in M.M.C.A.

\section{METHODOLOGY}

\section{Sampling technique and data collection}

The study was conducted in Maiduguri Metropolitan Council Area. A survey was used to collect primary data from ten yoghurt processing industries. This list was compiled from different sales points and confirmed from NAFDAC office as the number of registered yoghurt processors in Maiduguri.

The instrument used for data collection was a semi-structured questionnaire and data collected were on age, gender, marital status, household size, educational level, and years of experience in yoghurt processing, price of inputs, income, quantity of yoghurt produced, sales, marketing cost, etc.

\section{Analytical Tool}

The tools employed for the analysis of data were descriptive statistics and the profit model. Profit is traditionally the difference between total revenue and total cost of production. The various costs components involved and the revenue generated from the industries were itemized.

The profit model used to determine the profitability of yoghurt production is expressed as:

$$
\pi_{\mathrm{y}}=\mathrm{TR}_{\mathrm{y}}-\mathrm{ATC}_{\mathrm{y}}
$$

$$
\begin{array}{ll}
\text { Where: } & \\
\pi_{\mathrm{y}}= & \begin{array}{l}
\text { Mean profit obtained from processing } \\
25 \mathrm{~kg} \text { powdered milk } \\
\text { bag into yoghurt (\#) }
\end{array} \\
\mathrm{MTR}_{\mathrm{y}}= & \begin{array}{l}
\text { Mean Total Revenue from processing } \\
25 \mathrm{~kg} \text { powdered milk } \\
\text { bag into yoghurt (\#) }
\end{array} \\
\mathrm{MTC}_{\mathrm{y}}=\quad \begin{array}{l}
\text { Mean Total Cost of processing 25kg } \\
\text { powdered milk } \\
\text { bag into yoghurt (\#) }
\end{array} \\
\mathrm{AFC}_{\mathrm{y}}+\mathrm{AVC}_{\mathrm{y}}
\end{array}
$$

$$
\begin{aligned}
& \text { Where: } \\
& \mathrm{MFC}_{\mathrm{y}}=\text { Mean Fixed cost of processing } 25 \mathrm{~kg} \\
& \text { powdered milk bag into Yoghurt (\#) for } \\
& \text { all the sampled industries } \\
& \mathrm{MVC}_{\mathrm{y}}=\text { Mean variable cost of procesing } 25 \mathrm{~kg} \\
& \text { powdered milk bag into yoghurt (\#) } \\
& \mathrm{MTR}_{\mathrm{y}}=\mathrm{P}_{\mathrm{y}} \times \mathrm{MQ}_{\mathrm{y}}
\end{aligned}
$$

Where:

$$
\begin{array}{lll}
\mathrm{P}_{\mathrm{y}} & =\quad \text { Price of processed yoghurt ( } \\
\mathrm{MQ}_{\mathrm{y}} & =\quad \text { Mean quantity of processed yoghurt }
\end{array}
$$

\section{Findings and Discussion}

1. Socio-economic characteristics of yoghurt proprietors

The socio-economic characteristics of sole proprietors of yoghurt processing industries in Maiduguri Metropolitan area studied include age group, gender, marital status, household size, educational level attained and years of experience in yoghurt processing. (See table 1).

Analyses of Table 1 revealed that majority $(70 \%)$ of the respondents were males while $30 \%$ were females. The age group of yoghurt proprietors revealed that $60 \%$ of them are in the active age-group of $36-45$ years of age. The implication is that the proprietors can withstand the rigours involved in processing yoghurt.

The table further shows that most of the proprietors $(80 \%)$ earn annual incomes of over N200,000 while only $20 \%$ of them earn between $\mathrm{N} 100,000$ - N199,000 per annum. None of the proprietors earned incomes lower than $\mathrm{N} 100,000.00$. This implies that proprietors of yoghurt processing industries in Maiduguri are among the medium to high income earners in the country as categorized by Goni et al., (2007). Sixty percent (60\%) of the proprietors had experience of 6-10 years with $30 \%$ having completed primary education. However, about $40 \%$ completed tertiary education which was an indication of the level of managerial expertise put into the production process. Highly educated persons were expected to be better managers as education enhances a person's ability to deal with economic disequilibrium (Schultz, 1975).

With $60 \%$ of the proprietors having family size of 6-10 people and $80 \%$ of them being married, it can be inferred that they would always try to maximize their profits so as to be able to meet family responsibilities. 
Table 1: Socio-economic characteristics of proprietors of yoghurt processing industries in Maiduguri Metropolitan area

\begin{tabular}{|c|c|c|c|}
\hline $\mathrm{S} / \mathrm{N}$ & Variables & Frequency & Percentage \\
\hline \multirow[t]{3}{*}{1.} & Gender & & \\
\hline & Male & 7 & 70 \\
\hline & Female & 3 & 30 \\
\hline \multirow[t]{4}{*}{ II. } & Age-group (years) & & \\
\hline & $<35$ & 2 & 20 \\
\hline & $36-45$ & 6 & 60 \\
\hline & $>46$ & 2 & 20 \\
\hline \multirow[t]{4}{*}{ III. } & Annual Income (’000) & & \\
\hline & $<99$ & - & - \\
\hline & $100-199$ & 2 & 20 \\
\hline & $>200$ & 8 & 80 \\
\hline \multirow[t]{4}{*}{ IV. } & Production experience (years) & & \\
\hline & $<5$ & 3 & 30 \\
\hline & $6-10$ & 6 & 60 \\
\hline & $>11$ & 1 & 10 \\
\hline \multirow[t]{6}{*}{ V } & Educational level completed & & \\
\hline & Qur'anic & 1 & 10 \\
\hline & Primary & 3 & 30 \\
\hline & secondary & 2 & 20 \\
\hline & Tertiary & & 40 \\
\hline & & 4 & \\
\hline \multirow[t]{4}{*}{ VI } & Household size (No. of people) & & \\
\hline & $<5$ & 4 & 40 \\
\hline & $6-10$ & 6 & 60 \\
\hline & $>11$ & - & - \\
\hline \multirow[t]{4}{*}{ VII } & Marital Status & & \\
\hline & Single & - & - \\
\hline & Married & 8 & 80 \\
\hline & Divorced/widowed & 2 & 20 \\
\hline \multirow[t]{5}{*}{ VIII } & Number of Employee & & \\
\hline & Minimum & 4 & - \\
\hline & Maximum & 7 & - \\
\hline & Total & 50 & - \\
\hline & Mean & 5 & - \\
\hline
\end{tabular}


Table 2a: Fixed cost pro-rated into number of days in a year and total cost of producing yoghurt from $25 \mathrm{~kg}$ powdered milk bag

\begin{tabular}{llll}
\hline & \multicolumn{2}{c}{ Amount (\#) } & \\
\cline { 2 - 3 } Item & Minimum & Maximum & Average \\
\hline Rents & 136.98 & 191.78 & 164.38 \\
Labour ** & $1,700.00$ & $2,166.00$ & $1,933.00$ \\
Basins \& sealers & 14.25 & 14.25 & 14.25 \\
Tax & 46.57 & 46.57 & 46.57
\end{tabular}

$\begin{array}{llll}\text { Variable Cost } & & & \\ \text { Milk } & 32,500.00 & 33,500.00 & 33,000.00 \\ \text { Miscellaneous*** } & 330.00 & 350.00 & 340.00 \\ \text { Total } & 32,830.00 & 33,850.00 & 33,340.00 \\ \text { Total cost } & 34,727.80 & 36,268.60 & 35,387.53\end{array}$

Source: Survey data, 2007

* Pro-rated into Number days in a year

** - salaries of a manager @ N30,000/month and 4 workers @ N7,000/month

*** - Miscellaneous (water, starter culture \& additives)

Table 2b: Average Revenue and Profit from processing a 25kg Powdered Milk bag into Yoghurt

\begin{tabular}{ll} 
Item & Amount (N) \\
\hline Output (57 Jumbo bags) & \\
Price & $800 / \mathrm{Jumbo}$ bag \\
Average Revenue & $45,600.00$ \\
Average Total Cost & $35,387.53$ \\
Average Profit & $9,612.47$
\end{tabular}

Source: Survey data, 2007

* Min output = 55 Jumbo bags; Max. output 59 Jumbo bags

$* *$ Each jumbo bag $=20 \times 33 \mathrm{cl}$ bottle yoghurt

Table 3: Problems Affecting Yoghurt Processing in Maiduguri Metropolitan Area

\begin{tabular}{lll}
\hline Item & Frequency & Percentage* $^{*}$ \\
\hline Storage problem & 7 & 70 \\
High cost of inputs & 5 & 50 \\
Low demand & 4 & 40 \\
\hline
\end{tabular}

Source: Survey data, 2007

* Multiple response exist, hence total percentage greater than 100 


\section{Costs and return Analysis of Yoghurt Production} in Maiduguri

In order to determine the profitability of yoghurt production, the various cost components and revenue generated there from were itemized as indicated in Tables $2 \mathrm{a}$ and $2 \mathrm{~b}$. Table $2 \mathrm{a}$ indicated that the minimum total cost of processing a $25 \mathrm{~kg}$ milk bag into yoghurt is \#34,727.80k, a maximum total cost of $336,268.60 \mathrm{k}$ and an average total cost of $\$ 35,387.53 \mathrm{k}$.

A mean revenue of $\$ 45,600.00$ was realized from the sales of an average output of 57 jumbo bags of processed yoghurt at $\# 800 / j u m b o$ bag. This gives an average profit of $\$ 9,612.47 \mathrm{k}$ (Table $2 \mathrm{~b}$ ).

With a mean return on capital invested of about $27.2 \%$, yoghurt processing enterprise can rightly be concluded as profitable in the study area. This is more so if one compares this rate of return with the cost of capital in the economy (i.e. interest rate) which is between $17-23 \%$ per annum (CBN, 2006).

\section{Employment opportunities}

Employment is defined by the BBC English Dictionary as a position of having a paid job. By this definition, when someone is paid at the end of certain period for doing a specified task, then that person is employed.

The study revealed that the lowest number of persons employed per firm was four (4) persons and the highest was seven (7) (see table 1). It means that the yoghurt industries provided employment opportunities on the average for about five (5) persons per firm in the study area as they are paid at the end of the month for the services they performed thereby contributing to poverty reduction.

Other employment opportunities provided by the yoghurt industries were the large number of marketers and hawkers that were self-employed and depend on the sales of yoghurt at different sale points to make some financial gain. These group of people can be seen selling chilled yoghurt in cold boxes on bicycles, stalls, shops and supermarkets.

\section{Problems of Yoghurt Processing}

The major problems identified in yoghurt production in the study area are shown in Table 3 . These include storage problem, high cost of raw materials and low demand for the product.

Storage problem caused by the epileptic power supply in Maiduguri and improper packaging of products were the complaints of the majority of the producers (70\% of respondents). This makes yoghurt deteriorate in quality, thereby reducing the shelf life and demand of such products.

High cost of inputs was the second problem affecting over $50 \%$ of the yoghurt processors in the study area. The cost of inputs especially powdered milk greatly reduces the profit level. This low return may exert a negative supply response in production as producers may be discouraged to go into large production (Sulumbe, et al., 2007).

Seasonality of product is another problem facing $40 \%$ of the processors in the study area. This happens especially during the rainy season and harmattan period when the intake of chilled drinks and foods are reduced.
This low demand for yoghurt at such periods affects the revenue generation of the industries which serves as a disincentive for expanding production.

\section{CONCLUSION AND RECOMMENDATIONS}

The study assessed yoghurt processing industries in Maiduguri Metropolitan area with the view of determining its potentials for reducing poverty and creating job opportunities. Based on the findings on the profitability of the yoghurt processing (mean profit of N9,612.47k per $25 \mathrm{~kg}$ powdered milk processed into yoghurt) and the fact that five (5) persons on the average were employed in each yoghurt processing industry, it can be concluded that investments in yoghurt processing can create job opportunities and reduce poverty in the area.

In order to improve upon its role in job creation and poverty reduction, the following recommendations are made:-

i. Government should do everything possible to improve on the epileptic electricity supply in the study area. This will solve storage problems as processors can use refrigerators with constant electricity to prevent spoilage of products.

ii. Cooperatives could be formed by the processors to facilitate bulk purchase from powdered milk manufacturers. This will reduce the cost of powdered milk as such arrangements would by-pass the middlemen in the marketing of the product leading to reduced cost of powdered milk.

iii. Product development should be embarked upon by yoghurt processors so that products whose demand is not affected by weather e.g. cheese be developed and marketed especially during the rainy season and harmattan periods.

\section{REFERENCES}

Ajakaiye, D. O. and Adeyeye, V. A., 2001. "Concepts, Measurements and Causes of Poverty". Central Bank of Nigeria Economic and Financial Review, 39 (4) 8-44.

Booth, C., 1989. Labour and life of the people of London. 17 Volumes, Macmillan, London.

Boukar, K. G. M., 2004. "Financial Analysis of Sole proprietor Yoghurt Processing Industries in Maiduguri Metropolitan Area of Borno State." A B.Sc. Project submitted to the Department of Agric Economics \& Extension, University of Maiduguri, Nigeria.

CBN 2006: Annual Reports and Statement of Accounts 68 for the Year, Abuja, Nigeria

Fakiyesi, O. M. Encouraging Growth to Reduce Poverty in Nigeria". Central Bank of Nigeria Economic and Financial Review. 39(2): 61-91.

Federal Ministry of Labour and Productivity., 2004: "Employment and Poverty Alleviation in Nigeria". Background paper presented for African Union 
Extraordinary Summit on Employment and Poverty Alleviation in Africa, Ouagadougou, Burkina-Faso, $18^{\text {th }}-19^{\text {th }}$, September.

F.G.N., 2004: "Implementation of the Contributory Pension Scheme in the Public Service of the Federation". Circular No. HCSF/C/503/11/96, Office of the Head of Service of the Federation, Abuja.

Goni, M., Amaza, P.S. and Sulumbe, I. M., 2007. "Poverty and Food Insecurity in Northern, Borno State of Nigeria". Journal of Applied Sciences, Vol. 10, No.3.

Innovative Experiences 1998: Household Food Security and Nutrition ion Kano State, Nigeria. United Nations Development Programme, Special Unit for Technical Cooperation among Developing Countries.
Okuneye, B., 2002. Livestock sub-sector in Nigeria: Challenges and Prospects. Central Bank of Nigeria Bullion, Vol.26, No.3.

Schultz, T. W., 1975. The value of the Ability to Deal with Disequilibria". Journal of Economics Literature No.3 pp. 827-846

Sulumbe, I. M., Hussaini, R. and Goni, M., 2007. Structure and Performance of Rice Marketing in Maiduguri and Jere Local Government Areas of Borno State, Nigeria, African Journal of Sciences, Vol. 8, No.1

World Bank (2007)."World Development Indicators 2007". Washington D.C., U.S.A.

Joshua, A., 1999. The Role of Private Sector and How to Maximize the Use of Private Sector for Accelerating Food Production/Poverty Alleviation. A paper presented at the IITA/ABU Methodology Stakeholders Input Workshop on Food Production, Food Security, Food Demand, Structure and Marketing in Nigeria. September $7^{\text {th }}-9^{\text {th }}$, Kaduna, Nigeria. 

